\title{
Suspended-Sediment Loads in the Lower Stillaguamish River, Snohomish County, Washington, 2014-15
}

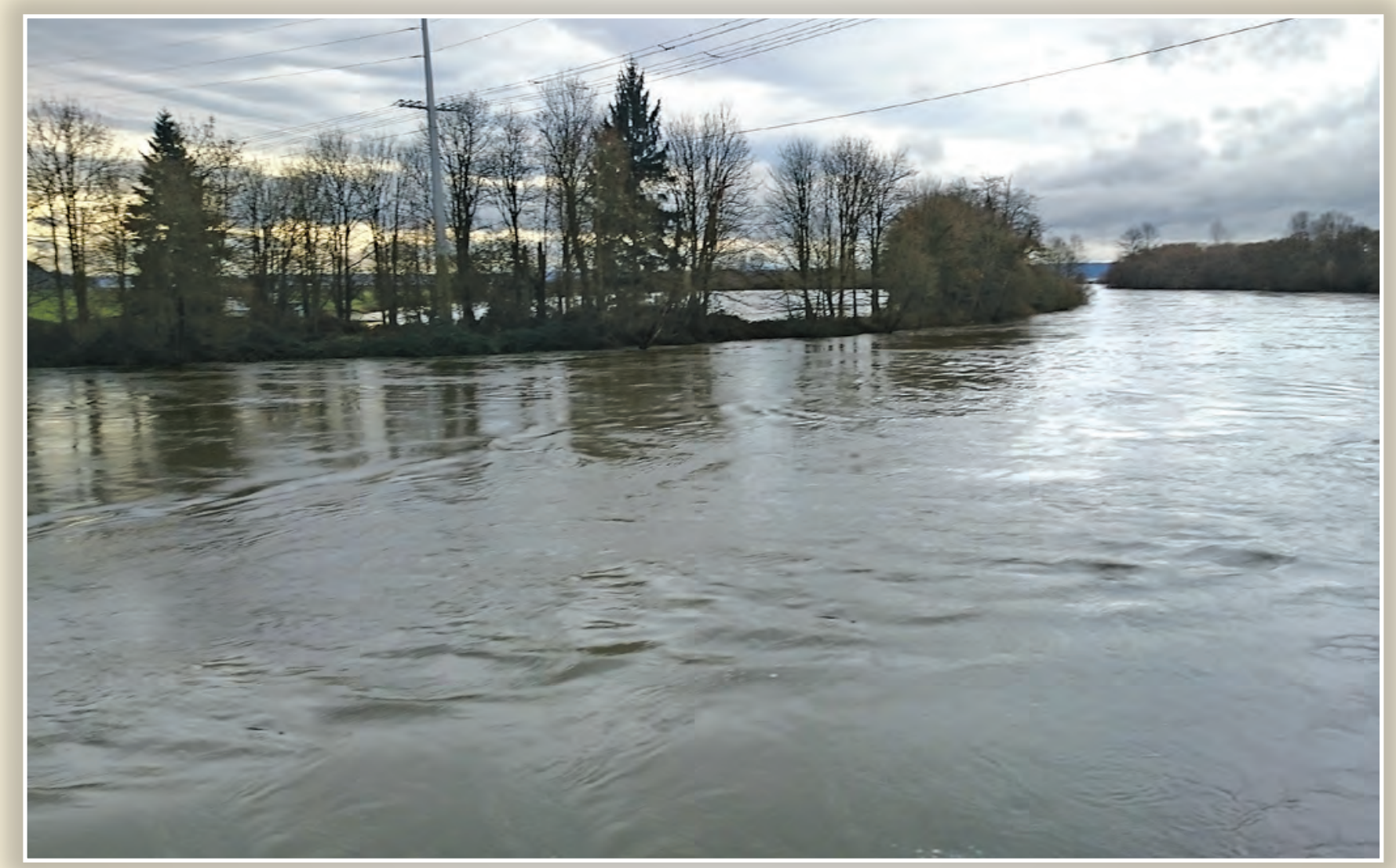

Open-File Report 2017-1066 
Cover: Photograph of Stillaguamish River. (Photograph taken November 26, 2014, by Chris Curran, U.S. Geological Survey.) 


\section{Suspended-Sediment Loads in the Lower Stillaguamish River, Snohomish County, Washington, 2014-15}

By Scott W. Anderson, Christopher A. Curran, and Eric E. Grossman

Open-File Report 2017-1066

U.S. Department of the Interior

U.S. Geological Survey 


\section{U.S. Department of the Interior \\ RYAN K. ZINKE, Secretary}

\section{U.S. Geological Survey \\ William H. Werkheiser, Acting Director}

U.S. Geological Survey, Reston, Virginia: 2017

For more information on the USGS—-the Federal source for science about the Earth, its natural and living resources, natural hazards, and the environment-visit https://www.usgs.gov/ or call 1-888-ASK-USGS (1-888-275-8747).

For an overview of USGS information products, including maps, imagery, and publications, visit https://store.usgs.gov.

Any use of trade, firm, or product names is for descriptive purposes only and does not imply endorsement by the U.S. Government.

Although this information product, for the most part, is in the public domain, it also may contain copyrighted materials as noted in the text. Permission to reproduce copyrighted items must be secured from the copyright owner.

Suggested citation:

Anderson, S.W., Curran, C.A., and Grossman, E.E., 2017, Suspended-sediment loads in the lower Stillaguamish River, Snohomish County, Washington, 2014-15: U.S. Geological Survey Open-File Report 2017-1066, 10 p., https://doi.org/10.3133/ofr20171066.

ISSN 2331-1258 (online) 


\section{Contents}

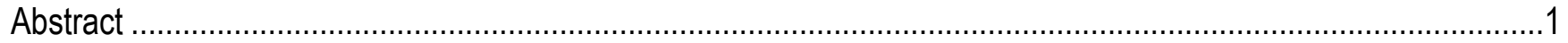

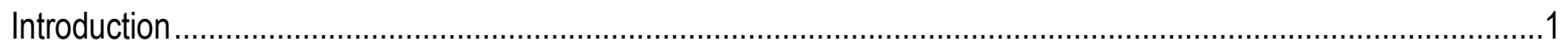

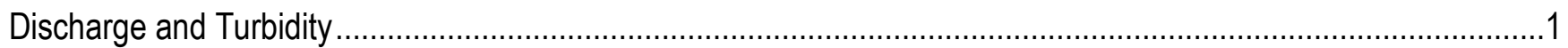

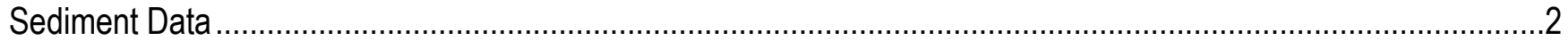

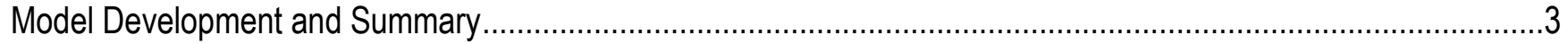

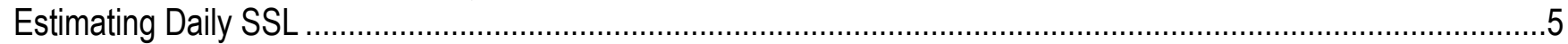

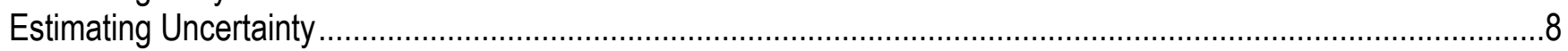

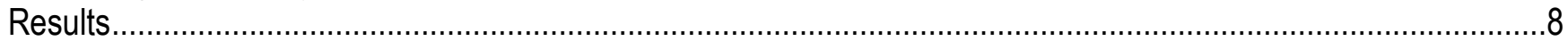

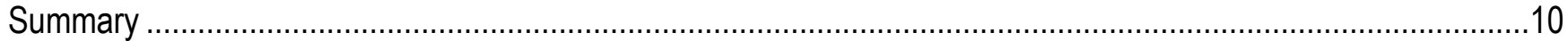

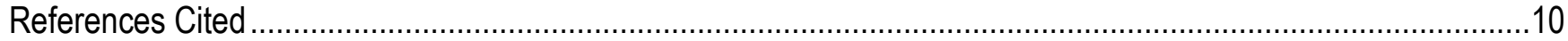

\section{Figures}

Figure 1. Graphs showing relation between turbidity and suspended-sediment concentration (SSC) at Stillaguamish River near Stanwood, Washington (USGS streamgage 12170300) 3

Figure 2. Graphs showing regression between daily mean discharge and daily suspended-sediment load at Stillaguamish River near Stanwood, Washington (USGS streamgage 12170300)

Figure 3. Graphs showing discharge, turbidity, and cumulative suspended sediment loads (SSLs) at Stillaguamish River near Stanwood, Washington (USGS streamgage 12170300) from November 2013 through September 2015

\section{Tables}

Table 1. Suspended-sediment concentration samples collected at Stillaguamish River near Stanwood,

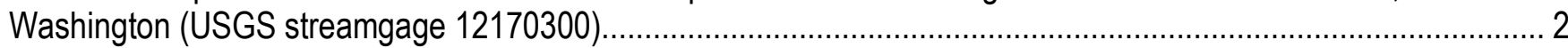

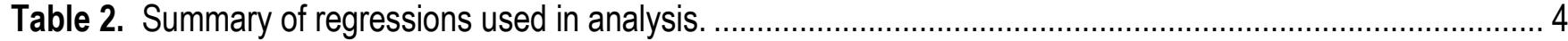

Table 3. Daily suspended-sediment loads at the Stillaguamish River near Stanwood, WA streamgage (USGS 12170300)

Table 4. Suspended-sediment loads for water years 2014 and 2015, Stillaguamish River near Stanwood, Washington (USGS streamgage 12170300) 


\section{Conversion Factors}

U.S. customary units to International System of Units

\begin{tabular}{|c|c|c|}
\hline Multiply & By & To obtain \\
\hline \multicolumn{3}{|c|}{ Volume } \\
\hline cubic foot per second $\left(\mathrm{ft}^{3} / \mathrm{s}\right)$ & 0.02832 & cubic meter per second $\left(\mathrm{m}^{3} / \mathrm{s}\right)$ \\
\hline \multicolumn{3}{|c|}{ Mass } \\
\hline ton, short $(2,000 \mathrm{lb})$ & 0.9072 & metric ton $(t)$ \\
\hline \multicolumn{3}{|c|}{ International System of Units to U.S. customary units } \\
\hline Multiply & By & To obtain \\
\hline \multicolumn{3}{|c|}{ Length } \\
\hline millimeter $(\mathrm{mm})$ & 0.03937 & inch (in.) \\
\hline
\end{tabular}

Concentrations of chemical constituents in water are given in milligrams per liter (mg/L). 


\title{
Suspended-Sediment Loads in the Lower Stillaguamish River, Snohomish County, Washington, 2014-15
}

\author{
By Scott W. Anderson, Christopher A. Curran, and Eric E. Grossman
}

\begin{abstract}
Continuous records of discharge and turbidity at a U.S. Geological Survey (USGS) streamgage in the lower Stillaguamish River were paired with discrete measurements of suspended-sediment concentration (SSC) in order to estimate suspended-sediment loads over the water years 2014 and 2015. First, relations between turbidity and SSC were developed and used to translate the continuous turbidity record into a continuous estimate of SSC. Those concentrations were then used to predict suspendedsediment loads based on the current discharge record, reported at daily intervals. Alternative methods were used to in-fill a small number of days with either missing periods of turbidity or discharge records. Uncertainties in our predictions at daily and annual time scales were estimated based on the parameter uncertainties in our turbidity-SSC regressions. Daily loads ranged from as high as 121,000 tons during a large autumn storm to as low as -56 tons, when tidal return flow moved more sediment upstream than river discharge did downstream. Annual suspended-sediment loads for both water years were close to $1.4 \pm 0.2$ million tons.
\end{abstract}

\section{Introduction}

This report documents the process of calculating daily suspended-sediment loads (SSL) in the lower Stillaguamish River between November 2013 and September 2015, based on 15-minute discharge and turbidity data collected at the U.S. Geological Survey (USGS) streamflow station at Stillaguamish River near Stanwood, Washington (USGS 12170300). Continuous estimates of suspended-sediment concentrations (SSC) were made based on a regression between measured SSC and turbidity, which were then used to estimate SSLs based on concurrent discharge records.

\section{Discharge and Turbidity}

Discharge at the site was tidally-influenced and was estimated using index-velocity methods described in Levesque and Oberg (2012). Turbidity was collected using a Nephelometric turbidity sensor (DTS-12). Standard USGS protocols were used in the calibration and maintenance of waterquality sensors and the collection of continuous data (Wagner and others, 2006). All 15-minute data collected at the site are available from the USGS National Water Information System (NWIS) website http://waterdata.usgs.gov/wa/nwis/uv?site_no=12170300. 


\section{Sediment Data}

Thirteen SSC samples were collected between November 19, 2013, and October 21, 2016 (table 1) using a mix of equal-discharge increment and equal-width increment methods, all of which followed guidelines set out in Edwards and Glysson (1999). Each SSC sample was analyzed by the Cascade Volcanoes Observation sediment laboratory for total SSC and the fraction of material finer than 0.063 millimeter, referred to here as "fine material." Of the 13 samples, 2 were collected during a period without available turbidity records. Three samples with concurrent turbidity data were collected in the days immediately following the March 22, 2014, State Route 530 (SR 530) Landslide, and were composed of 99 percent fine material. Because turbidity sensors typically are placed high in the water column, they accurately sample variations in the fine sediment, which is usually well-mixed in the vertical. However, turbidity sensors may miss variations in the sand component of the suspendedsediment load, which tends to remain closer to the bed. As a result, these three samples plot in line with other samples in terms of the turbidity-fine SSC relation, but plot low in terms of the turbidity-SSC relation (fig. 1). These three samples were then omitted from the turbidity-SSC regression but retained in the regression between fine SSC and turbidity. In total, 8 measurements were available for the regression between SSC and turbidity, and 11 measurements were available for the regression between fine SSC and turbidity. SSC measurements were made at a range of turbidities covering the full range of turbidities recorded over the 2-year period of record.

Table 1. Suspended-sediment concentration samples collected at Stillaguamish River near Stanwood, Washington (USGS streamgage 12170300).

$\left[\mathrm{ft}^{3} / \mathrm{s}\right.$, cubic feet per second; FNU, Formazin Nephelometric Units; $\mathrm{mg} / \mathrm{L}$, milligram per liter; SSC, suspended-sediment concentration; mm, millimeter; -, no data]

\begin{tabular}{cccccrc}
\hline Date & $\begin{array}{c}\text { Start } \\
\text { time }\end{array}$ & $\begin{array}{c}\text { End } \\
\text { time }\end{array}$ & $\begin{array}{c}\text { Discharge } \\
\text { (ft3/s) }\end{array}$ & $\begin{array}{c}\text { Turbidity } \\
\text { (FNU) }\end{array}$ & $\begin{array}{r}\text { SSC } \\
(\mathbf{m g} / \mathbf{L})\end{array}$ & $\begin{array}{c}\text { Percent } \\
\text { less than } \\
\mathbf{0 . 0 6 3} \\
\mathbf{m m}\end{array}$ \\
\hline $11-19-2013$ & 1400 & 1430 & 26,600 & - & 799 & 67 \\
$01-11-2014$ & 1345 & 1430 & 30,500 & - & 1,780 & 72 \\
$03-24-2014$ & 1415 & 1730 & 4,340 & 1,670 & 1,760 & 99 \\
$03-25-2014$ & 1130 & 1215 & 3,490 & 800 & 866 & 99 \\
$03-27-2014$ & 1415 & 1500 & 4,880 & 880 & 1,000 & 99 \\
$05-05-2014$ & 1530 & 1615 & 18,300 & 330 & 720 & 62 \\
$10-14-2014$ & 1300 & 1400 & 10,700 & 370 & 940 & 64 \\
$10-31-2014$ & 1215 & 1300 & 12,500 & 350 & 430 & 78 \\
$11-26-2014$ & 1230 & 1330 & 40,900 & 730 & 1,230 & 62 \\
$12-09-2014$ & 1530 & 1600 & 8,620 & 65 & 176 & 67 \\
$01-05-2015$ & 1230 & 1330 & - & 940 & 1,570 & 62 \\
$02-06-2015$ & 1730 & 1815 & 24,300 & 520 & 932 & 61 \\
$10-21-2016$ & 1145 & 1215 & - & 180 & 498 & 45 \\
\hline
\end{tabular}



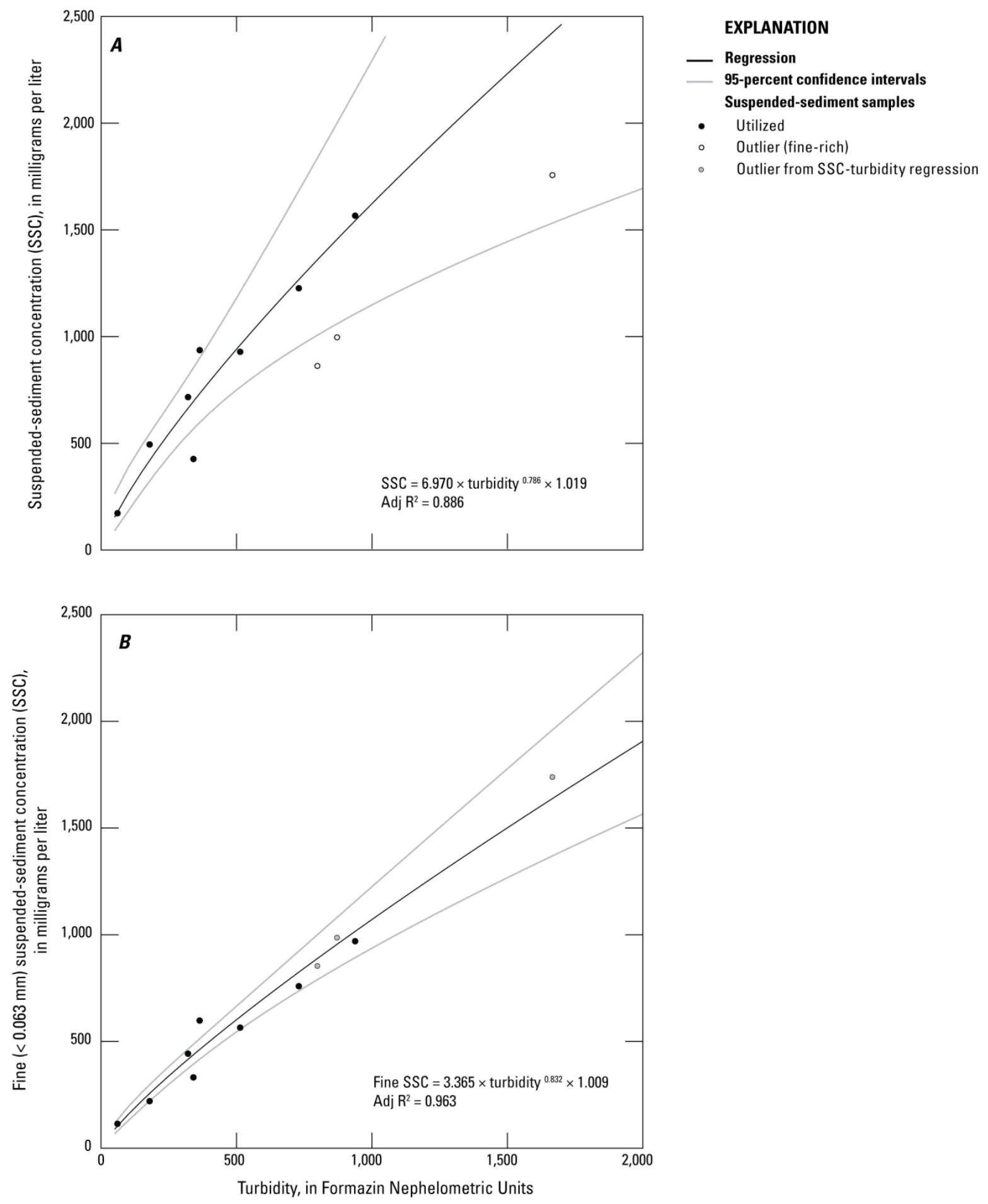

Figure 1. Graphs showing relation between turbidity and suspended-sediment concentration (SSC) at Stillaguamish River near Stanwood, Washington (USGS streamgage 12170300). (A) Results for total SSC. Powerlaw rating curve derived from ordinary-least squares regression on the log-transformed values is shown. Three finerich samples taken in the days immediately after the SR 530 Landslide have been excluded from the regression. $(B)$ Same as $(A)$, except for the fine fraction of the SSC (material less than 0.063 millimeter in diameter). The three samples excluded from the SSC-turbidity regression plot with the rest of the data and were retained in the finefraction regression. 


\section{Model Development and Summary}

Relations between turbidity and measured SSC were developed and used to estimate SSL following methods presented in Rasmussen and others (2009). Measured SSC and measured fine SSC show a strong relation with turbidity (fig. 1). The data support either a simple linear relation or a loglinear relation (power law). The power law relation was selected for this analysis primarily based on the desirable property of forcing the regression through the zero-zero point, avoiding unrealistically high SSC estimates during low-flow conditions.

Ordinary least squares (OLS) regression was used to estimate the relation between the log-10 values of turbidity and the $\log -10$ values of SSC. This regression was then re-transformed from logunits to natural units $r$ to estimate SSC and SSL. This retransformation produces log-normal residuals in untransformed space, introducing bias. This bias was accounted for using Duan's (1983) bias-correction factor, which was calculated to be 1.019. The final regression, after retransformation and accounting for the bias correction, was

$$
\text { SSC }=6.97 * \text { turbidity }^{0.786} * 1.019
$$

where

SSC is the suspended-sediment concentration in milligrams per liter, and turbidity in Formazin Nephelometric Units.

This same process was repeated for the relation between the log-10 values of turbidity and the $\log -10$ values of the fine SSC, resulting in a final model of:

$$
\mathrm{SSC}_{\text {fine }}=3.365 * \text { turbidity }^{0.832} * 1.009
$$

Summary statistics for both regressions are shown in table 2 .

Table 2. Summary of regressions used in analysis.

[DMD, daily mean discharge; $\mathrm{ft}^{3} / \mathrm{s}$, cubic feet per second; FNU, Formazin Nephelometric Units; $\mathrm{mg} / \mathrm{L}$, milligram per liter; SSC, suspended-sediment concentration; SSL, suspended-sediment

\begin{tabular}{|c|c|c|c|}
\hline \multicolumn{4}{|c|}{ Regression: SSC (mg/L) Turbidity (FNU) } \\
\hline \multirow{2}{*}{$\begin{array}{c}\text { Summary statistic } \\
\text { Number of observations }\end{array}$} & \multicolumn{3}{|c|}{ Statistic value } \\
\hline & 8 & & \\
\hline Standard error & 0.1021 & & \\
\hline Coefficient of determination $\left(\mathrm{R}^{2}\right)$ & 0.9 & & \\
\hline Adjusted coefficient of determination & 0.886 & & \\
\hline $\mathrm{p}$ value & 0.0003 & & \\
\hline Bias correction factor & 1.019 & & \\
\hline Explanatory variables & Value & Standard error & P-value \\
\hline Intercept & 0.8432 & 0.2698 & 0.02 \\
\hline $\log 10$ (Turbidity) & 0.7862 & 0.1057 & 0.0003 \\
\hline \multicolumn{4}{|c|}{ Final equation, $\log$ units: $\log 10(\mathrm{SSC})=0.7862 * \log 10$ (turbidity) +0.8432} \\
\hline \multicolumn{4}{|c|}{ Final equation, back-transformed: $\mathrm{SSC}=6.97 *$ turbidity $^{0.1 / 802} * 1.019$} \\
\hline
\end{tabular}
load; <, less than] 


\begin{tabular}{|c|c|c|c|}
\hline \multicolumn{4}{|c|}{ Regression: Fine SSC (mg/L) Turbidity (FNU) } \\
\hline Summary statistic & Statistic value & & \\
\hline Number of observations & 11 & & \\
\hline Standard error & 0.063 & & \\
\hline Coefficient of determination $\left(\mathrm{R}^{2}\right)$ & 0.967 & & \\
\hline Adjusted coefficient of determination & 0.961 & & \\
\hline $\mathrm{p}$ value & $<<0.0001$ & & \\
\hline Bias correction factor & 1.009 & & \\
\hline Explanatory variables & Value & $\begin{array}{l}\text { Standard } \\
\text { error }\end{array}$ & P-value \\
\hline Intercept & 0.526 & 0.138 & 0.004 \\
\hline $\log 10$ (Turbidity) & 0.832 & 0.051 & $<<0.0001$ \\
\hline \multicolumn{4}{|c|}{ Final equation, $\log$ units: $\log 10($ fine $S S C)=0.832 * \log 10$ (turbidity $)+0.526$} \\
\hline \multicolumn{4}{|c|}{ Final equation, back transformed: fine $\mathrm{SSC}=3.365 *$ turbidity ${ }^{0.832} * 1.009$} \\
\hline \multicolumn{4}{|c|}{ Regression: Daily SSL (tons/day) Daily mean discharge $\left(\mathrm{ft}^{3} / \mathrm{s}\right)$} \\
\hline Summary statistic & Statistic value & & \\
\hline Number of observations & 509 & & \\
\hline Standard error & 0.222 & & \\
\hline Coefficient of determination $\left(\mathrm{R}^{2}\right)$ & 0.948 & & \\
\hline Adjusted coefficient of determination & 0.948 & & \\
\hline $\mathrm{p}$ value & $<<0.0001$ & & \\
\hline Bias correction factor & 1.153 & & \\
\hline Explanatory variables & Value & $\begin{array}{l}\text { Standard } \\
\text { error }\end{array}$ & P-value \\
\hline Intercept & -5.028 & 0.081 & $<<0.0001$ \\
\hline $\log 10$ (daily mean discharge) & 2.243 & 0.023 & $<<0.0001$ \\
\hline \multicolumn{4}{|c|}{ Final equation, $\log$ units: $\log 10(\mathrm{SSL})=2.243 * \log 10(\mathrm{DMD})-5.028$} \\
\hline \multicolumn{4}{|c|}{ Final equation, back-transformed: $\mathrm{SSL}=9.362 * 10^{-0} * \mathrm{DMD}^{2.243} * 1.153$} \\
\hline \multicolumn{4}{|c|}{ Regression: Daily fine SSL (tons/day) Daily mean discharge $\left(\mathrm{ft}^{3} / \mathrm{s}\right)$} \\
\hline Summary statistic & Statistic value & & \\
\hline Number of observations & 509 & & \\
\hline Standard error & 0.235 & & \\
\hline Coefficient of determination $\left(\mathrm{R}^{2}\right)$ & 0.946 & & \\
\hline Adjusted Coefficient of determination & 0.945 & & \\
\hline $\mathrm{p}$ value & $<<0.0001$ & & \\
\hline Bias Correction factor & 1.174 & & \\
\hline Explanatory variables & Value & $\begin{array}{c}\text { Standard } \\
\text { error }\end{array}$ & P-value \\
\hline Intercept & -5.552 & 0.086 & $<<0.0001$ \\
\hline $\log 10$ (daily mean discharge) & 2.318 & 0.0246 & $<<0.0001$ \\
\hline \multicolumn{4}{|c|}{ Final equation, $\log$ units: $\log 10(\mathrm{SSL})=2.318 * \log 10(\mathrm{DMD})-5.552$} \\
\hline Final equation, back-transformed: SSL & $10^{-6} * \mathrm{DMD}^{2.3}$ & 1.174 & \\
\hline
\end{tabular}




\section{Estimating Daily Suspended-Sediment Load}

The application of the regression equations for total and fine SSC was used to produce estimates of the sediment concentration for every 15 -minute time stamp with a valid turbidity value. These estimates of concentrations were then converted to SSL by multiplying by the concurrent discharge:

$$
S S L=\mathrm{k} * S S C * Q,
$$

where

SSL is the suspended-sediment load, in tons,

$Q \quad$ is the discharge, in cubic feet per second, and

$\mathrm{k} \quad$ is a constant $2.809 * 10^{-5}$ that accounts for unit conversions.

For days with complete 15-minute records, estimates of daily loads were computed by summing the individual 15-minute estimates of SSL. Days with minor gaps (less than 10 percent missing) in either the turbidity record or discharge record were filled with linear interpolation to create a complete set of 15-minute estimates (table 3).

Table 3. Daily suspended-sediment loads at the Stillaguamish River near Stanwood, WA streamgage (USGS 12170300).

[Table is available for download at https://doi.org/ofr20171066]

SSL for days where the turbidity record was more than 10 percent incomplete were estimated using a regression between daily mean discharge and SSL, using the data from the days with complete records (fig. 2). The period between March 22, and April 15, 2014, was omitted from this regression, because the relation between discharge and SSL was substantially disrupted by sediment input from the SR 530 Landslide. The relation was described using a power law, calculated using OLS regression on the log-transformed values of discharge and SSL, and then retransformed back to untransformed units to estimate SSLs. Duan's (1983) bias correction factor was again calculated to account for retransformation bias. The final regression for total SSL was

$$
\text { dailySSL }=9.362 * 10^{-6} * D M D^{2.243} * 1.153
$$

and the regression for fine SSL was

$$
\text { dailySSL }_{\text {fine }}=2.802 * 10^{-6} * D M D^{2.318} * 1.174
$$

where

dailySSL and

dailySSLfine are the daily suspended-sediment load in tons and daily fine suspended-sediment

load, in tons, respectively, and

DMD is the daily mean discharge, in cubic feet per second (table 2).

Although these regressions exclude the several weeks immediately after the SR 530 Landslide, these regressions still are likely to include some influence of sediment input from the landslide, and are not considered valid for estimating daily SSL outside the period of record presented here. In total, there were 20 days when daily SSL was estimated based on discharge, including 2 days in which the discharge was first estimated from a stage-discharge relation. The cumulative SSL during that 20 day period was 310,000 tons, representing about 10 percent of the period of record SSL. 


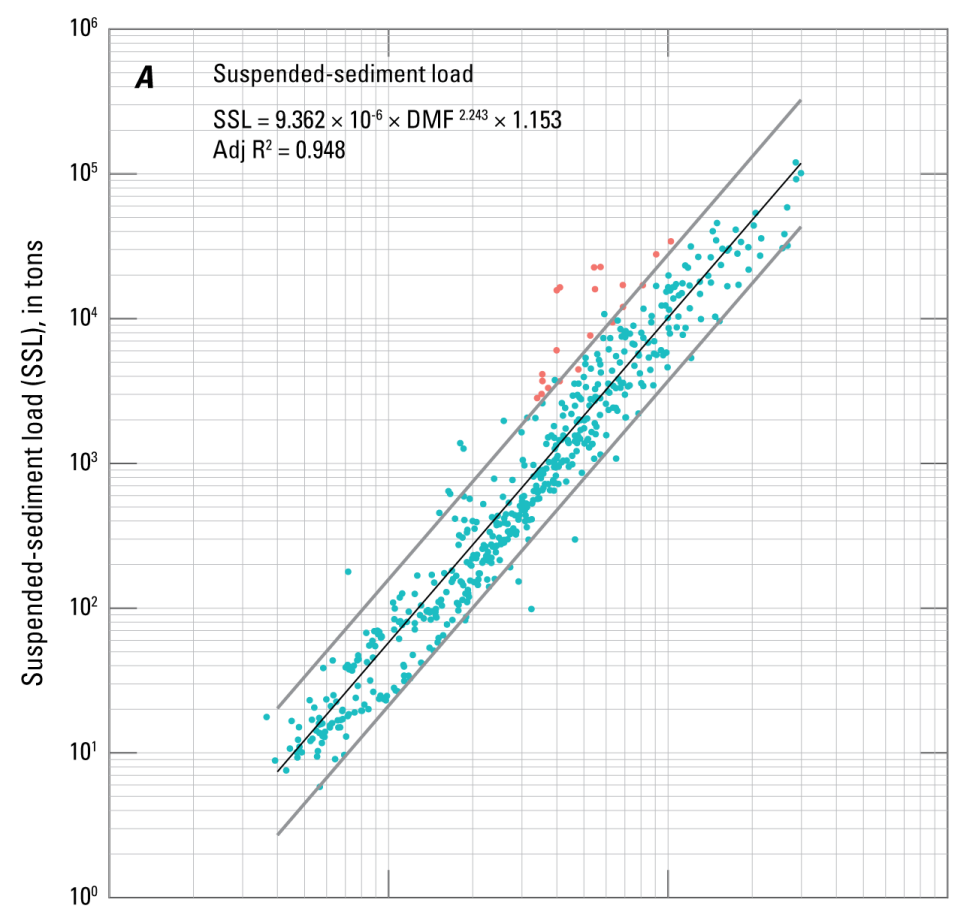

EXPLANATION
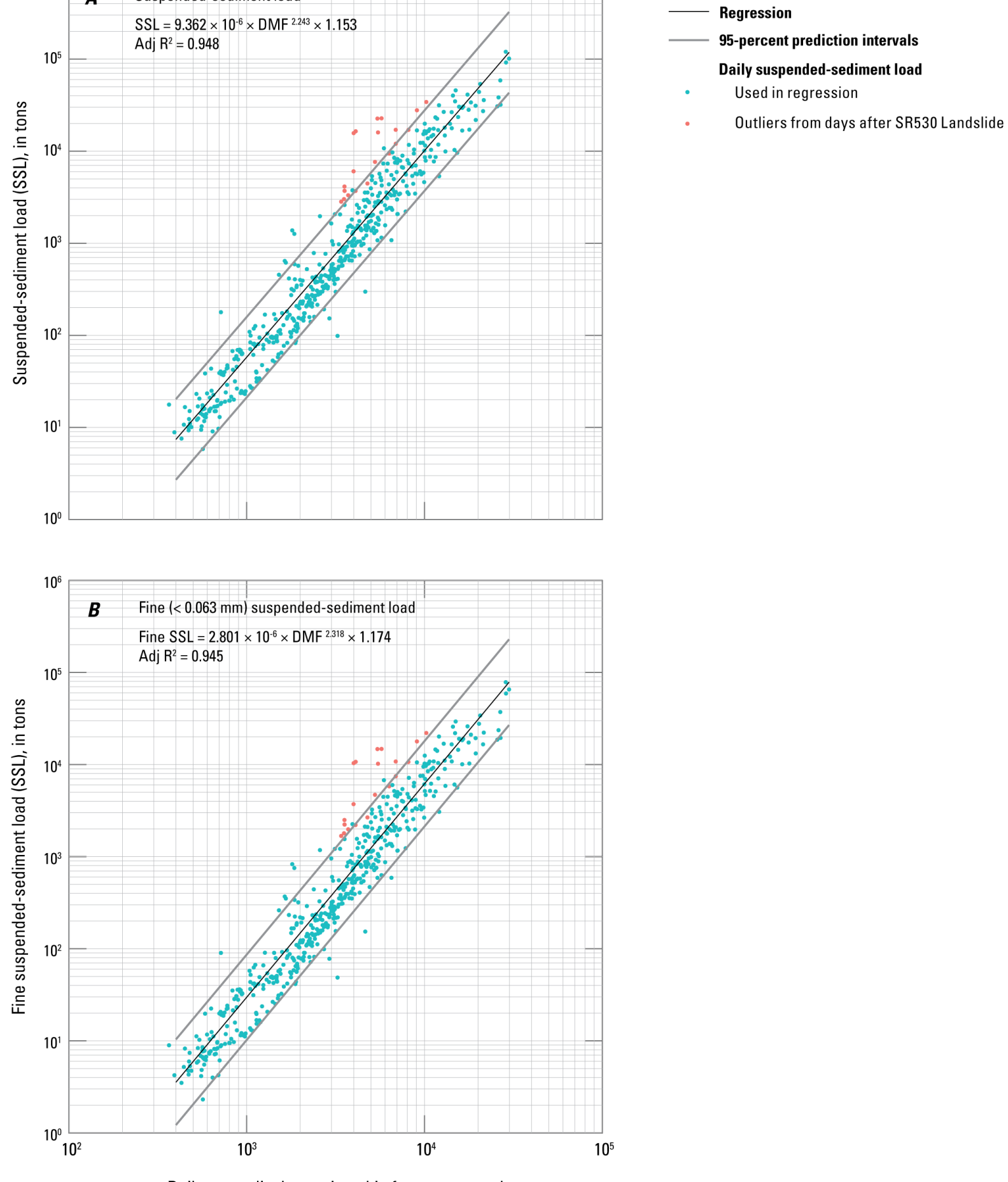

Daily mean discharge, in cubic feet per second

Figure 2. Graphs showing regression between daily mean discharge and daily suspended-sediment load at Stillaguamish River near Stanwood, Washington (USGS streamgage 12170300). Only data for which complete 15minute data records were available were used. Data recorded between March 22 and April 15, 2014, were excluded, because the loads were anomalously high due to sediment input from the SR 530 Landslide. 
There were 8 days in the period of record for which no estimates of daily mean flow were available. Only 2 of these days were during periods of low discharge and turbidity, and when daily discharge at an upstream streamgage (North Fork Stillaguamish River near Arlington, USGS 12167000) was not changing substantially. Daily SSL in those 6 low-flow days were then estimated using linear interpolation of the SSL based on the days prior and subsequent to the missing days. There were 6 days where SSLs were estimated using linear interpolation, with an estimated cumulative SSL of 700 tons representing less than 0.1 percent of the SSL for the period of record. The remaining 2 days of missing discharge records (January 5-6, 2015) occurred during a period of high and rapidly changing discharges. Daily mean discharges for those 2 days were estimated by constructing an approximate stage-discharge rating curve based on days with complete records. These estimated discharges were then used to estimate the SSLs based on equations (4) and (5).

The period of record in the weeks following the March 22, 2014, SR 530 Landslide is complete, with daily SSL estimated using equations (1) and (2). However, SSC samples collected on March 24, 25 , and 27, 2014, were all composed of 99 percent fine material, indicating that only the silt and clay from the landslide was passing the site (table 1). For the period between March 24 and 27, 2014, the total SSL was then assumed to be equal to the estimated fine SSL, because no sand was in transport. An SSC sample collected on May 5, 2014, contained 62 percent fines, similar to samples collected before the landslide and most samples collected after this date, indicating that the fine-rich conditions immediately after the landslide were temporary and lasted no longer than about 5 weeks. In the absence of any information about if and when sand from the landslide began to arrive the Stanwood site, all daily SSL after March 27, 2014, were estimated using equation (1) for the daily SSL.

\section{Estimating Uncertainty}

Uncertainty in the estimates of SSL was calculated as a function of the uncertainty of the parameters estimated from OLS regression. For days with complete 15-minute data, the uncertainty of each 15-minute estimate was propagated into the daily estimate using the methods described in Gilroy and others (1990). Uncertainty of the annual estimates also was propagated using these methods. All uncertainties are presented as 95 percent prediction intervals.

\section{Results}

Over the nearly 2-year period of record, the cumulative SSL at the Stanwood site was $2.9 \pm 0.4$ million tons, of which approximately $1.8 \pm 0.1$ million tons (about 65 percent) was fine material less than 0.063 millimeter in diameter (fig. 3, tables 3 and 4). Annual SSL in both water year 2014 and water year 2015 were around $1.4 \pm 0.2$ million tons. Although the period of record does not include the first 6 weeks of water year 2014, the period of record encompasses all major high-flow events, and the underestimate of the annual SSL is not likely to be large. The magnitude of daily SSL ranged from -56 tons, when tidal flow moved more sediment upstream than downstream, to 121,000 tons during high flows on November 4, 2014. 

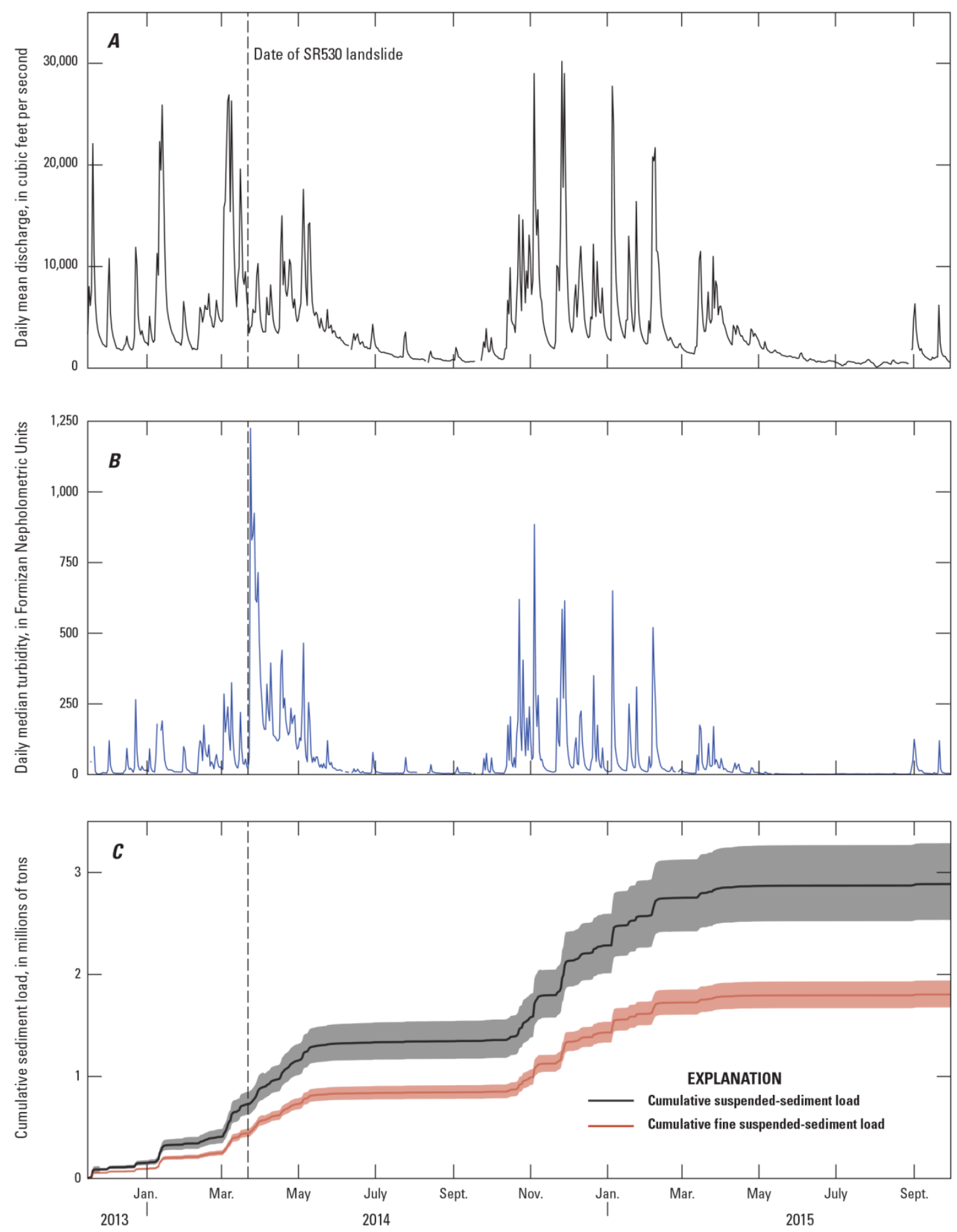

Figure 3. Graphs showing discharge, turbidity, and cumulative suspended-sediment loads (SSLs) at Stillaguamish River near Stanwood, Washington (USGS streamgage 12170300) from November 2013 through September 2015. (A) Daily mean discharge; (B) Median turbidity; (C) Cumulative SSL and fine SSL estimated using discharge and turbidity records and the derived suspended-sediment concentration turbidity rating curve. Shading indicates 95 percent confidence intervals in cumulative load estimates. Dashed lines indicate the date of the SR 530 Landslide in all plots. 
Table 4. Suspended-sediment loads for water years 2014 and 2015, Stillaguamish River near Stanwood, Washington (USGS streamgage 12170300).

\begin{tabular}{|c|c|c|}
\hline $\begin{array}{l}\text { Water } \\
\text { year }\end{array}$ & $\begin{array}{l}\mathrm{SSL} \\
\text { (tons) }\end{array}$ & $\begin{array}{c}\text { Fine SSL } \\
\text { (tons) }\end{array}$ \\
\hline $2014^{1}$ & $1,350,000 \pm 200,000$ & $850,000 \pm 70,000$ \\
\hline 2015 & $1,530,000 \pm 190,000$ & $960,000 \pm 60,000$ \\
\hline
\end{tabular}

${ }^{1}$ Period of record from October 1, 2013, to November 14, 2013, is unavailable.

\section{Summary}

Continuous records of discharge and turbidity were paired with discrete measurements of suspended-sediment concentration in order to estimate suspended-sediment loads in the lower Stillaguamish River over water years 2014 and 2015. Annual suspended-sediment loads for the 2 water years were both around $1.4 \pm 0.2$ million tons and were dominated by transport during large autumn and winter storms.

\section{References Cited}

Duan, N., 1983, Smearing estimate-A nonparametric retransformation method: Journal of the American Statistical Association, v. 78, no. 383, p. 605-610.

Edwards, T.K., and Glysson, D.G., 1999, Field methods for measurement of fluvial sediment: U.S. Geological Survey Techniques of Water-Resources Investigations, book 3, chapter C2, 89 p. [Also available at https://pubs.usgs.gov/twri/twri4a3/html/toc.html.]

Gilroy, E.J., Hirsch, R.M., and Cohn, T.A., 1990, Mean square error of regression-based constituent transport estimates: Water Resources Research, v. 26, no. 9, p. 2,069-2,077.

Levesque, V.A., and Oberg, K.A., 2012, Computing discharge using the index velocity method: U.S. Geological Survey Techniques and Methods, book 3, chap. A23, 148 p. [Also available at https://pubs.usgs.gov/tm/3a23/.]

Rasmussen, P.P., Gray, J.R., Glysson, G.D., and Ziegler, A.C., 2009, Guidelines and procedures for computing time-series suspended-sediment concentrations and loads from in-stream turbidity-sensor and streamflow data: U.S. Geological Survey Techniques and Methods, book 3, chap. C4, 53 p. [Also available at http://pubs.usgs.gov/tm/tm3c4/.]

U.S. Geological Survey, 2017, National Water Information System: U.S. Geological Survey website, accessed March 10, 2017, at http://waterdata.usgs.gov/wa/nwis/uv?site_no=12170300.

Wagner, R.J., Boulger, R.W., Jr., Oblinger, C.J., and Smith, B.A., 2006, Guidelines and standard procedures for continuous water-quality monitors - Station operation, record computation, and data reporting: U.S. Geological Survey Techniques and Methods, book 1, chap. D3, 94 p. [Also available at https://pubs.usgs.gov/tm/2006/tm1D3/.] 
Publishing support provided by the U.S. Geological Survey

Science Publishing Network, Tacoma Publishing Service Center

For more information concerning the research in this report, contact the Director, Washington Water Science Center

U.S. Geological Survey

934 Broadway, Suite 300

Tacoma, Washington 98402

http://wa.water.usgs.gov 
